\title{
Commodity Nomenclature and Classification of Goods for Customs Purposes in the Eurasian Economic Union' ${ }^{1}$
}

\section{凡目 Dmitry V. Korf}

Associate Professor, Department of Financial, Customs and Tax Law, Law Faculty, National Research University Higher School of Economics, Candidate of Juridical Sciences. Address: 20 Myasnitskaya Str., Moscow 101000, Russian Federation. E-mail: dkorf@hse.ru

\begin{abstract}
夆国 Abstract
The article presents one of the key customs law features - the customs nomenclature and classification of goods. The study demonstrates its multifunctional nature: its value for customs tariff regulation and the calculation of customs duties, its use for statistical purposes, and for the identification of goods when they are subject to non-tariff regulation. 181 million people living in the Eurasian Economic Union (EAEU) generated over 4.3 trillion U.S. dollars of yearly PPP-based gross domestic product as of $2015^{2}$. Within the customs union in the EAEU, members use a common external tariff to impose import customs duties on goods entering the union from the outside, and customs nomenclature used to build an external customs tariff serves also as the basis for trade negotiations amongst the EACU member states. The research examines the concepts of the Commodity Nomenclature of Foreign Economic Activity (CNFEA), its international standardization, the Harmonized Commodity Description and Coding System, the basic rules of customs classification, the legal organizational aspects of maintaining the CNFEA and the adoption of provisional decisions on the classification of goods. The history of the development of the international basis for nearly all customs nomenclatures known as the harmonized system is viewed as a continuous process in response to the sophistication of the structure of international trade. The massive growth in turnover of international goods is also considered as a driver for international negotiations on common unified customs nomenclature. However, the structure and volume of international trade turnover are constantly changing in a changing world. That is why maintaining and regularly updating the harmonized system is one of the main goals of the World Customs Organization (WCO) in its role as an intergovernmental organization designed to facilitate the free movement of goods and improve customs procedures among all of its members (individual states and the EU).
\end{abstract}

\section{O-1}

Customs Union, Eurasian Economic Union, customs legislation, the commodity nomenclature, foreign economic activity, classification of goods for customs purposes.

${ }^{1}$ The article was prepared within the framework of Academic Fund Program at National Research University Higher School of Economics (HSE) in 2016-2017 (grant № 16-01-0064) and supported within the framework of a subsidy granted to the HSE by the Government of the Russian Federation for the implementation of the Global Competitiveness Program.

${ }^{2}$ World Bank. International Comparison Program database. Available at: // http://data.worldbank.org/indicator/NY.GDP.MKTP.PP.CD 
Citation: Korf D.V. (2017) Commodity Nomenclature and Classification of Goods for Customs Purposes in Eurasian Economic Union // Pravo. Zhurnal Vysshey shkoly ekonomiki, no 2, pp. 188-198 ((in English)

DOI: 10.17323/2072-8166.2017.2.188.198

The classification of goods for customs purposes represents a feature of customs law that provides uniformity in the customs tariff regulation of foreign trade transactions.

The Commodity Nomenclature of Foreign Economic Activity (henceforth CNFEA), which is used for the purposes of customs classification, is multifunctional and has become an important legal means without which it is impossible to apply, in practice, any method of state regulation concerning foreign trade.

CNFEA is the systematized nomenclature of goods and their corresponding codes of commodity groups, headings, subheadings and notes. It includes general and specific rules of classification, that is, definition of the code of a material product by the commodity nomenclature is obligatory. This distinguishes the commodity nomenclature used for customs purposes from any other cases - CNFEA is always the basis of customs tariffs. The procedure of determining the code of goods by CNFEA (alternatively known as tariff equating) have an important economic and legal value.

First, the rate of customs duty and consequently the customs tariff burden on foreign trade operations depend on its customs heading.

Second, the commodity nomenclature is used for determining the non-tariff measures of state regulation (licenses, quotas) that are subject to application in respect of particular foreign trade transactions.

Third, the commodity nomenclature represents he basis for maintaining customs statistics, which allow the analysis of a foreign trade turnover and on this basis develop future customs and foreign trade policy.

Forth, CNFEA serves as the basis for trade negotiations between Eurasian Economic Union member states.

Maintaining CNFEA enhances and modernizes commodity nomenclature, bringing it into compliance with the statistical customs requirements for international trade and with the changes brought by the modernization of international legal basis of CNFEA.

The legal base of the commodity nomenclature used in the Eurasian Economic Union (henceforth EAEU) is constituted by the Harmonized Commodity Description and Coding System of the World Customs Organization (henceforth HS) and the Commodity Nomenclature of Foreign Economic Activity of the Commonwealth of Independent States (henceforth CNFEA CIS), therefore changes in HS followed by the changes of CNFEA. However, this modern form of customs commodity nomenclature was the result of a long historical process.

Until the early 19th century, the range of goods exchanged in international trade was relatively narrow because there had been only a slight increase in industrial production. Medieval customs tariffs very often contained only a few dozen items of goods. Hence, there was no need to group descriptions of goods or to apply a coding system. Under those conditions, countries often used an alphabetical list as a simple nomenclature for customs tariffs. For example, this technique was used to list goods in the Russian Customs Tariff in $1724^{3}$. Even now, listing goods in alphabetical order is sometimes used in devising codes of export customs duties when the number of goods subject to duties is relatively small. All the same, it should be noted that almost all countries also use HS nomenclature for convenience when they establish their export customs duties.

\footnotetext{
${ }^{3}$ Lebedev V. I. Reformy Petra I [Reforms of Peter I]. Moscow, 1937. P. 48-51.
} 
Today, the method of grouping goods in alphabetical order is often used in various tax laws that establish different rates for different categories of goods, but this approach does not apply to import customs tariffs.

Indeed, the ordering of customs classifications of goods became an issue only when the total number of kinds of goods subject to customs duties was more than several hundred. This condition was not met until the first half of the 19th century as a result of the boom in industrial production, primarily in Western Europe and the New World, with a corresponding expansion of the list of goods exchanged in international trade.

The states reacted to this change in the structure of international trade by elaborating the commodity nomenclature (from the Latin word nomenclatura meaning "list") of their customs tariffs in the 19th century, as more and more national producers demanded that their governments protect them from foreign competition by imposing high customs duties on imported goods.

Each state independently decided how to protect its domestic producers from foreign competition. In some cases they would completely ban the import of certain goods from certain countries, but more often a protectionist policy in state regulation of foreign trade resulted in high rates for customs duties.

Such policies not only complicated the commodity nomenclature of import customs tariffs, but also created additional inconveniences for importers and exporters who had to classify their goods several times as they crossed customs borders where different tariff nomenclatures were based on different criteria for classification. If we consider that in the 19th century transit customs duties were also widely levied, the difficulties that traders encountered at that time were by no means insignificant.

In addition, these conditions made comparison of the statistical data on the foreign trade of different states extremely difficult. Thus, between 1831 and 1854 Belgium summarized foreign trade statistics by grouping it into three categories according to the degree of processing of products: "raw materials", "edible products in the natural state", and "manufactured products". After 1854 Belgium nevertheless had to return to "alphabetical order" because of many other European countries continued to apply alphabetical nomenclatures to goods while collecting customs duties and compiling statistical reports on foreign trade.

This approach used in Belgium, as well as in some other European countries, led to a discussion of how to combine and unify the principles for grouping goods in the nomenclature of customs tariffs and statistical nomenclatures at an international level.

In 1853 the first International Statistical Congress was held in Brussels where recommendations on the unification of customs nomenclatures for statistical purposes were adopted. Participants in this Congress also favored a uniform international tariff nomenclature as the basis for international statistical nomenclature.

The Statistical Congress of 1853 recommended that the statistical nomenclatures of most states be developed in close connection with the nomenclatures of their customs tariffs, and a change in one of them should be reflected in similar changes to the other. The creation of a single international basis, according to which states would construct the nomenclature of national customs tariffs, was proposed as a mechanism for such changes.

The Convention concerning the Creation of an International Union for the Publication of Customs Tariffs, Regulations for the Execution and Memorandum of Signature was adopted in Brussels on 5 July 1890. According to Article XII of the Convention, in order to enable the International Union to produce its Bulletin International with as much exactitude as possible, the contracting parties were to submit, directly and promptly, two copies of their customs tariff, carefully corrected and up to date. 
This was the first attempt to gather in one place all national customs tariffs and rules. Some Russian researchers note that cooperation between states in customs matters began with this Convention ${ }^{4}$.

The Convention regarding the unification of commercial statistics was signed on December 31, 1913 in Brussels, and it concerned mainly the harmonization of international statistics. The parties to the Convention agreed to provide the International Bureau of Foreign Trade Statistics each year with information that conformed to a unified list of goods. This treaty was the first harmonized system for describing and coding goods used in foreign trade, and this system was used not only for statistical purposes, but also as a basis for building national customs tariffs.

By the beginning of the 1920s, the nomenclature established by the 1913 Convention no longer met the needs of the states for effective regulation of customs and tariffs or the statistical needs of other users because the goods exchanged in foreign trade had become more and more diverse; and a more detailed classification was demanded. A new nomenclature was prepared under the League of Nations. Between 1931 and 1937 an ad hoc committee of experts on statistics, established by the Economic Committee of the League of Nations, prepared a new version of the "Draft Customs Nomenclature", which would be suitable for economic and statistical analysis of foreign trade. What resulted was the commodity nomenclature of 1937, which was called the Minimum List of Commodities for International Trade Statistics of the League of Nations, also known as the Geneva Nomenclature of $1938^{5}$.

The Geneva nomenclature of 1938 is based on two criteria for classification, one of which, the principle of the use of goods, prevails over the other, grouping by type of material. The nomenclature was a classification of a vertical type and consisted of 17 sections, 50 groups and 456 basic commodity items. A little later, the Minimum List of Goods for International Trade Statistics was used by the United Nations as the basis for the construction of the Standard International Trade Classification (UN / SITC).

WWII interrupted international cooperation in harmonizing national customs tariff nomenclatures. On December 15, 1950, the Convention on the Establishment of the Customs Cooperation Council was signed in Brussels, and it came into force on November 4, 1952. Also on December 15, 1950 in Brussels the parties signed the Nomenclature Convention for the classification of goods in customs tariffs ${ }^{6}$.

Further development of a single international customs tariff nomenclature for goods had already been carried out with the direct participation of the Council of Customs Cooperation, now known as the World Customs Organization (WCO).

The annex to the 1950 Convention, which entered into force on 11 September 1959, became known as the "Brussels Tariff Nomenclature" (BTN). In 1974 the BTN was renamed, and the last edition of the Brussels nomenclature of 1978 was called "Nomenclature of the Council of Customs Cooperation".

Many states have applied the BTN without participating in the Convention as a whole. The lack of any international legally binding obligation of states and customs unions to make appropriate changes in their nomenclature has often caused published versions of national customs tariffs and trade statistics to lag behind the most recent format that has a basis in international law.

4 Sandrovskij K. K. (2002) Mezhdunarodnoe tamozhennoe pravo [International Customs Law]. Kiev, 2002, p. 162.

${ }^{5}$ League of Nations, 1938 (II.A.14; and corrigendum, 1939).

${ }^{6}$ Australian Treaty Series. 1978. № 18. 
The sophistication of the structure of international trade by the end of the 20th century, the exigencies of international organizations and states in the qualitatively new instruments of the international control of cross-border movement of particular goods, including those which constitute danger to persons, the necessity of implementing continuous monitoring of the foreign trade of species which are under threat of extinction, the avalanche-like increase in the turnover of international goods and the use of computer technologies in customs affairs, and the acceleration of customs procedures - all of these factors led to the need for a unification of customs classifications for modern international trade and the formation of a universal international customs classification-HS.

On June 14, 1983 at the session of the Customs Co-operation Council (currently the World Customs Organization) in Brussels the final version of the International Convention on HS was approved. The Convention came into force on January 1, 1988. ${ }^{7}$ In the Russian Federation, the Convention came into force on January 1, 1997 (The Resolution of the Government of the Russian Federation from April 3, 1996 № 372) ${ }^{8}$.

The unification of commodity nomenclatures and the formation of HS are the grounds for the simplification and development of foreign trade, the reduction of expenses incurred by the participants of foreign trade which relate to repetitive description, classification, and the coding of goods upon their transition from one classification system to another in the course of international trade.

HS represents the global international customs commodity nomenclature and system of coding the mechanism of maintaining and updating of which best responds to technological shifts in international trade. HS is used as a tool of international trade negotiations within the WTO.

The establishment of free trade areas or customs unions in many parts of the world began with the creation of a unified customs nomenclature based on HS. In this regard we point out some of the trade zones and unions are using a common unified customs tariff classification of goods:

Central American Integration System (S.I.C.A.) with their Harmonized Tariff Classification System or Sistema Arancelario Centroamericano (S.A.C.);

MERCOSUR and their common nomenclature;

Caribbean Community (CARICOM) Common External Tariff (CET) nomenclature;

Central African Economic and Monetary Community (CEMAC) Common External Tariff nomenclature;

Economic Community Of West African States (ECOWAS) ECOWAS Common External Tariff nomenclature;

Common Market for Eastern and Southern Africa (COMESA) Common Tariff nomenclature;

Gulf Co-operation Council (GCC) Unified Customs Tariff (2017) and its nomenclature;

The Combined Nomenclature of the Common Customs Tariff (EU).

Currently, 99.9\% customs and statistical nomenclatures of the world are based on HS. The CNFEA applied within the Customs Union of the EAEU is not an exception.

${ }^{7}$ International Convention on the Harmonized Commodity Description and Coding System (As amended by the Protocol of Amendment to the International Convention on the Harmonized Commodity Description and Coding System of June 24, 1986). Signed in Brussels on June 14, 1983. Entered into force on January 1, 1988. Available at: // URL: http://www.wcoomd.org/home_hsnomenclaturetable2012.htm [Website of World Customs Organization] (accessed: 26.03.2017)

${ }^{8}$ Resolution № 372 of the Government of the Russian Federation of April 3, 1996 "O prisoyedinenii Rossiiskoi Federatcii k Mezhdunarodnoi konventcii o garmonizirovanoi sisteme opisaniia i kodirovaniia tovarov". Sobranie zakonodatelstva Rossiiskoi Federatcii (SZ RF). 08.04.1996. N 15. Art. 1619. 
The nomenclature of HS includes:

a) commodity headings and subheadings;

b) the digital codes for headings and subheadings;

c) section, chapter, and subheading notes;

d) general rules of interpretation of the HS.

Amendments to the HS nomenclature imply an international legal obligation of each contracting party of the HS Convention within a fixed timeframe to bring into accordance with the supplemented HS their statistical and customs tariff or single customs statistical nomenclatures.

The contracting parties of the HS Convention are bound to the application of HS as a base for their customs statistical nomenclature, which is applied when declaring imported goods and which is used for the collection of statistical data on foreign trade transactions.

In case of developing national customs statistical commodity classification, a member of the HS Convention is not allowed to arbitrarily delete selected commodity headings and subheadings of HS, amend or supplement the first six digits of the HS code, or modify the established basic rules in the annex regarding the application of HS.

It is permitted to itemize the HS nomenclature by means of adding additional subsections that are coded with more digits than in the HS.

The distinctive feature of the classification scheme of HS is comprehensiveness. Sections I, II and V are constructed on the principle of origin, sections IV, XI, XII, XVII, XVIII, XIX, XX and XXI by functional assignment, sections III, VI, VII by chemical composition, and sections VIII, IX, X, XIII, XIV and XV by the category of the material from which the goods was made.

The chapters are allocated with different rule - the degree of good processing. Simplistically: live animals are classified in chapter 1, skin and leather of animals in chapter 41 , and leather footwear in chapter 64.

The HS nomenclature includes 21 sections (denoted in Roman numerals, the section number is not coded), which include chapters numbered from 1 to 97, also there are non-coded subchapters in the HS, 33 in total), the chapters are divided into commodity headings (1224), and most commodity headings are composed of two types of subheadings-with one dash and with two smaller hyphens (initially, there were 5019 subheadings in the HS) ${ }^{9}$.

In HS six-digit coding is applied. The code is read as follows: the first two digits indicate number of the chapter, the first four digits correspond to the number of the commodity heading inside the chapter, the first five digits mean the subheading with one dash belonging to a certain commodity heading, and the first six digits correspond to the final two-dash subheading belonging to a subheading of the first level (with one dash).

For example, the HS code 5202.91 means that the encoded goods belong to chapter 52 "Cotton", to the commodity heading 52.02 "Cotton waste (including yarn waste and garnetted stock)" of that chapter, and then to the subheading with one dash 5202.9 "yarn waste other" and finally to the commodity subheading with two dashes 5202.91 "garnetted stock", which belongs to the commodity subheading 52.02 .

If the corresponding commodity heading of HS is not divided into subheadings, the fifth and sixth digits of the code are converted to zero.

This nomenclature covers all possible types of goods. It means that even if there is no separate subheading allocated to a particular good in the HS nomenclature, it is still possible to assign a six-digit HS classification code to this good. This is possible using the so called "basket

${ }^{9}$ Berlin E.A., Ivanov N.A. Tovarnaia nomenklatura vneshneekonomicheskoi deiatelnosti SNG [Commodity Nomenclature of Foreign Economic Activity of the CIS]. Moscow, 1996. P. 84. 
provisions" of commodity headings, or using the "other" of commodity subheadings ${ }^{10}$, which classify the goods that are not named in other chapters.

The HS nomenclature requires itemization, which is explained by the necessities of effective tariff protection and the realization of more flexible fiscal policy by states and customs unions.

The classification of goods by the HS nomenclature signifies a phase-by-phase determination of its classification code, that is establishment of chapter, commodity heading and commodity subheading, and its corresponding six-digit code.

The procedure of customs equating, i.e. customs code assignment or encoding, is the application of the rules of interpretation for the unambiguous reference of goods to the HS subheading. There are two means that are used for interpretation of the HS nomenclature: internal, or official; and external, or recommendatory. General rules of interpretation that are included in the annexes of HS Convention and the notes to the sections, chapters, and subheadings belong to the former. The HS Explanatory Notes and the Collection (so-called "compendium") of Classification Opinions adopted by WCO based on HS Committee recommendations belong to the latter.

In accordance with Article 10 of the HS Convention, disputes between contracting parties concerning the interpretation or application of HS is settled by negotiation between them. The disputes that are not settled in this way are passed to the HS Committee, which considers the dispute and makes recommendations for its settlement. The occurrence of such disputes in practice is rare. There are relatively frequent latent collisions when the customs administrations of two states or WCO members prescribe the classifications of the same goods differently. Such hidden "disputes" are resolved in national courts, not by the HS Committee. At the same time, private entities can initiate discussion of a problem in the World Customs Organization through International Chamber of Commerce (ICC), which is invited as the representative of the private sector for participation as an observer in all meetings of HS Committee.

CNFEA CIS is one of the customs commodity nomenclatures that has derived from HS. It is applied in the territory of states that are signatories to the relevant agreement. CNFEA CIS represents itemization of the coding of HS nomenclature to the ninth digit.

Agreement established CNFEA CIS was signed on November 3, 1995 (hereinafter referred to as "the Agreement"). ${ }^{11}$ In this document, in particular it was established (Art.1) that the parties are creating single commodity nomenclature based on HS, in order to implement the tariff and non-tariff measures of the regulation of foreign economic activity, the advancement of maintaining statistical accounting, and the exchange of statistical information. The single nomenclature is provided in the Annex of the corresponding Agreement.

The peculiarity of CNFEA CIS lies in the fact that it is administered by the customs service of one of the contracting states, namely the Russian Federation. These powers are fixed in Article 2 of the Agreement and they state that the Federal Customs Service of Russia (FCSR) monitors changes of the international basis of CNFEA CIS, brings it into accordance with the HS nomenclature, maintains this nomenclature and stores a reference copy, and, at the request of the Council of Heads of the Customs Services, approves classification decisions on the interpretation of CNFEA CIS.

${ }^{10}$ What Every Member of the Trade Community Should Know about: Tariff Classification. Informational publication of the U.S. Customs and Border Protection. Available at: http://www.cbp.gov/linkhandler/ cgov/ trade/legal/informed_compliance_pubs/ icp017r2.ctt/icp017r2.pdf. [Website of the U.S. Customs and Border protection] (accessed: 23.12.2016).

11 The Agreement of the States of the CIS of November 3, 1995 "O Edinoi Tovarnoi Nomenklature vneshneekonomicheskoi deiatelnosti SNG” [About Single Commodity Nomenclature of Foreign Economic Activity of the Commonwealth of Independent States]. Rossiiskaia gazeta. 03.02.1996. N 22. 
Questions regarding the development of the explanations to the CNFEA CIS lie in joint competence of the customs services of states which are signatories to the Agreement.

The powers of FCSR on maintaining the single nomenclature are limited by the Agreement (Point 2 of Article 2), whereas decisions on the modification and supplementation of CNFEA CIS and explanations on the interpretation of the nomenclature shall be approved by the Council of Heads of Customs Services of the CIS states.

CNFEA CIS represents a nine-digit commodity nomenclature, out of which the first six digits completely correspond to the HS nomenclature and the three subsequent digits are subheadings, which belong to CNFEA CIS coding.

The seventh and eighth digits of code of the goods according to the CNFEA CIS, currently in most cases coincide with the Combined Nomenclature of the European Union. This is connected with the fact that the basis of CNFEA CIS - the CNFEA of Russia was developed with difficulty, therefore it was decided to use the subheadings of the Combined Nomenclature of the EU to code goods at the level of seventh and eighth digits, as the EU considered as one of the major international trading partner of Russia.

The shortcomings of the CNFEA CIS, related to its insufficient itemization, were eliminated with the Commodity nomenclatures, which were passed on the base of the CNFEA CIS and are itemization of the HS Nomenclature and the CNFEA CIS to the tenth digit:

The Commodity Nomenclature of Foreign Economic Activity of the Eurasian Economic Community (CNFEA EurAsEC);

The Commodity Nomenclature of Foreign Economic Activity of the Customs Union (CNFEA CU);

The Commodity Nomenclature of Foreign Economic Activity (CNFEA EAEU).

The functioning of CNFEA EAEU was approved by the Decision of the Eurasian Economic Commission on July 16, 2012 N 54 (with subsequent changes and supplements made) "About the Approval of the Single Commodity Nomenclature of Foreign Economic Activities of the Eurasian Economic Union and the Common Customs Tariff of the Eurasian Economic Union"12.

The powers to approve CNFEA EAEU supervene from:

1) The Agreement on the Functioning of the Customs Union within the Multilateral Trade System from May 19, 2011;

2) The Regulation of the Eurasian Economic Commission, approved by the Decision of the Supreme Eurasian Economic Council at the level of the heads of the states from November 18, 2011 № 1.

CNFEA EAEU is integrated into the Common Customs Tariff of the Eurasian Economic Union and represents its inalienable part.

The decisions on entering modifications and additions to CNFEA EAEU are made by the Eurasian Economic Commission ${ }^{13}$

12 Decision N 54 of the Eurasian Economic Commission of July 16, 2012 "Ob utverzhdenii Edinoi Tovarnoi Nomenklaturi vneshneekonomicheskoi deiatelnosti Tamozhennogo Soiuza i Edinogo Tamozhennogo Tarifa Tamozhennogo Soiuza" [About Approval of the Single Commodity Nomenclature of Foreign Economic Activities of the Customs Union and the Common Customs Tariff of the Eurasian Economic Union]. Available at: // URL: http://www.tsouz.ru/, 23.07.2012 [Website of the Eurasian Economic Union] (accessed: 26.03.2017)

${ }^{13}$ For instance, the Decision No 64 of the Council of the Eurasian Economic Commission of September 18, 2014 "O vnesenii izmenenii v Edinuiu tovarnuiu nomenklaturu vneshneekonomicheskoi deiatelnosti Tamozhennogo Soiuza i edinyi Tamozhennii Tarif Tamozhennogo Soiuza v otnoshenii otdelnih vidov pressovogo oborudovaniia dlia aviacionnoi promishlennosti" [On Entering Modifications to the Single Commodity Nomenclature of Foreign Economic Activity of the Customs Union and Common Customs Tariff of the Customs Union Concerning Separate Types of the Press Equipment for Aviation Industry]. Available at: // URL: http:// www.eurasiancommission.org/, 23.09.2014 [Website of the Eurasian Economic Union] (accessed: 26.03.2017). 
The acts of the Board of the Eurasian Economic Commission document explanations to the Commodity Nomenclature (Recommendation N 23 of the Board of the Eurasian Economic Commission "About Explanations to the Single Commodity Nomenclature of Foreign Economic Activity of the Eurasian Economic Union"14) and the classification decisions on certain types of goods (for example, the Decision of the Board of the Eurasian Economic Commission from September 16, 2014 N 157 "About Classification of Gauze Fabric by Single Commodity Nomenclature of Foreign Economic Activity of the Customs Union"15).

In cases of disputes over classification decisions and other matters concerned with the application of CNFEA EAEU, the dispute decisions are made by the Court of the EAEU. The technical maintenance of CNFEA EAEU is performed by the Secretary of the Eurasian Economic Commission and the Federal Customs Service, which include the Bureau of Commodity Nomenclature of the FCS of Russia.

The basis for the legal mechanism of the interaction between the supranational body and the Federal Customs Service concerning issues of the technical maintenance of the Commodity Nomenclature was enshrined in the Decision of the Commission of the Customs Union N 295 "About Documents Regarding Technical Maintenance of the Single Commodity Nomenclature of Foreign Economic Activity of the Customs Union"16.

The Russian legislation on customs regulation determines the main dimensions of the activities of the Bureau of Commodity Nomenclature of FCSR.

The Bureau participates in the fulfilment of Russia's obligations arising from its participation in the International Convention on Harmonized Commodity Description and Coding System of June 14, 1983 and the Agreement on the Single Nomenclature of Foreign Economic Activity of the Commonwealth of Independent States of 3 November 1995.

It also participates in the preparation of proposals for the development of state politicies in the field of customs affairs and their implementation in the maintenance and application of commodity nomenclatures of foreign economic activity.

The Bureau of Commodity Nomenclature of FCSR organizes and coordinates the activities of customs bodies concerning the accurateness of the classification of goods in accordance with CNFEA EAEU and the compliance of the adoption of preliminary decisions about the classification of goods in accordance with CNFEA EAEU.

In order to perform its corresponding tasks, the Bureau prepares Russian language versions of documents of the World Customs Organization concerning HS, develops proposals for the classification of certain goods in accordance with the CNFEA EAEU, and maintains the Col-

${ }^{14}$ Recommendation No 23 of the Board of the Eurasian Economic Commission "O poiasneniiakh k Edinoi Tovarnoi Nomenklature vneshneekonomicheskoi deiatelnosti Evraziiskogo Ekonomicheskogo Soiuza” [About Explanations to the Single Commodity Nomenclature of Foreign Economic Activity of the Eurasian Economic Union]. Available at: // URL: http://eaeunion.org/, 01.12.2016 [Website of the Eurasian Economic Union] (accessed: 26.03.2017).

15 Decision No 157 of the Board of the Eurasian Economic Commission "O klassifikatcii tkani marlevoi po Edinoi Tovarnoi Nomenklature vneshneekonomicheskoi deiatelnosti Tamozhennogo Soiuza” [About Classification of Gauze Fabric by Single Commodity Nomenclature of Foreign Economic Activity of the Customs Union]. Available at: // URL: http://www.eurasiancommission.org/ [Website of the Eurasian Economic Commission] (accessed: 26.03.2017).

16 Decision of the Commission of the Customs Union No 295 "O dokumentakh po teknnicheskomu vedeniiu Edinoi Tovarnoi Nomenklaturi vneshneekonoicheskoi deiatelnosti Tamozhennogo Soiuza” [About documents regarding the technical maintenance of the Single Commodity Nomenclature of Foreign Economic Activity of the Customs Union]. Available at: // URL: http://www.tsouz.ru/, 25.06.2010. [Website of the Customs Union Commission]. Entered into force on 1 July 2010. 
lection of preliminary decisions about classification of goods in accordance with the CNFEA EAEU, which is available on the website of FCSR.

The Customs Code of Customs Union ${ }^{17}$ (Art. 51) establishes for FCSR the following functions for technical management of CNFEA EAEU:

1) monitoring changes in the international framework of CNFEA, and explanations and solutions for the interpretation of this framework;

2) making proposals to the Eurasian Economic Commission of the customs union on bringing CNFEA into conformity with its international basis;

3) preparation for the publication and the direction of CNFEA and explanations for it to the Eurasian Economic Commission.

\section{Conclusions}

To summarize the analysis of the legal basis for the classification of goods for customs purposes within the EAEU, we note the following:

1. The procedures of customs classification and single commodity nomenclature are used for the identification of goods for customs purposes, and also, they provide a means of achieving uniformity of customs classification.

The unification of customs nomenclature that is used in world trade is one of the most vital tasks of the World Customs Organization and modern international customs law.

2. The classification of goods for customs purposes with the application of commodity nomenclature is used for regulating customs tariff and non-tariff international trade and maintaining foreign trade statistics.

The customs classification of goods and assignments of the corresponding code to this good from commodity nomenclature constitute the initial stage of the procedure of customs tariff regulation, that is determination of the amount of the customs duty, which is subject to payment for the movement of this good across the customs border. Only after determining the code of the goods according to the commodity nomenclature, it is possible to establish the rate of the customs duty that is subject to payment.

This classification also initiates the application of the instruments of non-tariff regulation (such as licenses, quotas) to the goods of international trade. Without the implementation of customs classification, administrative barriers in foreign trade cannot be used.

Both of these circumstances causes the most conflict in the procedures of the customs classification of foreign trade.

3. To minimize conflict in the customs classification of goods, legal means, such explanations by competent bodies of the application of commodity nomenclature and the adoption of preliminary decisions in assigning the commodity code for a particular good, are actively used.

When a dispute is not resolved in the pre-judicially, it is passed to the court.

4. In the EAEU, for the customs classification of goods participating in international trade, CNFEA is used. This represents the version of commodity nomenclature derived from HS the outcome of the World Customs Organization for the unification of national customs statistics for the classification of goods participating in international trade.

5. The basis for CNFEA, used in the Common Customs Tariff of the EAEU, is CNFEA CIS, which was enacted in 1995 by the post-soviet republics of the USSR after the conclusion of the corresponding international legal agreement. The CNFEA CIS is extremely close to the unified

17 Tamozhenii kodeks Tamozhennogo Soiuza [Customs Code of Customs Union] of November 11, 2009. Sobranie zakonodatelstva Rossiiskoi Federatcii. 13.12.2010. No 50. Art. 6615. 
versions of commodity nomenclatures: its first six digits coincide with HS; and the seventh and eighth digits with the Combined Nomenclature of the European Union. The itemization of the nomenclature for the ninth and tenth digits is under competence of EAEU.

6. The Eurasian Economic Commission (art. 54 of the Treaty on Eurasian Economic Union) is responsible for the maintenance of the Single Commodity Nomenclature of Foreign Economic Activity of the Eurasian Economic Union.

The power of the Eurasian Economic Commission to approve the Commodity Nomenclature is realized through the adoption of decisions by the Council of the Eurasian Economic Commission. Modifications and additions to the Commodity Nomenclature can be made by the decisions of the Council and the Board of the Eurasian Economic Commission.

The Board of Eurasian Economic Commission also prepares explanations of the Commodity Nomenclature (through adoption of Board recommendations) and the adoption of classification decisions on certain types of goods.

7. The technical maintenance of the Commodity Nomenclature is carried on by the Secretariat of the Eurasian Economic Commission and the FCSR, which includes the Bureau of Commodity Nomenclature.

The peculiarity of the Commodity Nomenclature of the EAEU is the delegation of the powers of the technical maintenance of the CNFEA EAEU to FCSR which carries it out on behalf of all EAEU, in accordance with the Customs code of the Customs union.

\section{正 References}

Berlin E.A., Ivanov N.A. (1996) Tovarnaia nomenklatura vneshneekonomicheskoi deiatelnosti SNG [Commodity Nomenclature of Foreign Economic Activity of the CIS]. Moscow: Rossiyskaia tamozhennaya akademia, 288 p. (in Russian)

Berr C. (2008) Introduction au droit douanier. Paris: Economica, 73 p.

Cabello Pérez M., Cabello Gonzale J. (2012) Las aduanas y el commercio international. Madrid: Editorial, $255 \mathrm{p}$.

Customs Modernization Handbook (2005) Ed. by L. De Wulf and J. Sokol. Washington: The World Bank, $302 \mathrm{p}$.

Fabio M. (2010) Customs Law of the European Union. Kluwer Law International, 725 p.

Giffoni M. (2012) La réglamentation douanière de l'Union européenne. Bruxelles: Anthemis, 407 p.

Kozyrin A. N. (2014) Tamozhennoe zakonodatelstvo Tamozhennogo soiuza EvrAzES [Customs Legislation of the EurAsEC Customs Union]. Zakony Rossii: opit, analiz, praktika, no. 4, pp. 3-7.

Kozyrin A. N. (2013) Mezhdunarodnii dogovori i natcionalnoe zakonodatelstvo v pravovom mekhanizme Tamozhennogo soiuza EvrAzES [International Treaties and National Legislation in the Legal Mechanizm of the EurAsEC Customs Union]. Reformy i pravo, no. 2, pp. 29- 36.

Lebedev V.I. (1937) Reformy Petra I [Reforms of Peter I]. Moscow: Gosudarstvennoie izdatelstvo, 379 p. (in Russian)

Masco B. (2013) Tratado de Aduanas e Impuestos Especiales. Madrid: Bosch, 319 p.

Sandrovskiy K.K. (2002) Mezhdunarodnoe tamozhennoe pravo [International Customs Law]. Kiev: Znania, 461 p. (in Russian)

Shokhin S.O. (2014) Mezhdunarodno-pravovii sapekti finansovoj deiatelnosti tamozhennih organov [International-law Aspects of Financial Activities of Customs Agencies]. Juridicheskij mir, no 5, p. 11-13.

Theule-Martin C. (1995) La douane: Instrument de la stratégie internationale. Paris: Economica, $111 \mathrm{p}$.

Udovenko S.P. (2006) Tamozhenni tarif sovremennoj Rossii (1993-2005) [Customs Tariff of Contemporary Russia (1993-2005)]. SPb.: Arkhej, 402 p.

Viner J. (2014) The Customs Union Issue. Oxford: OUP, 185 p. 